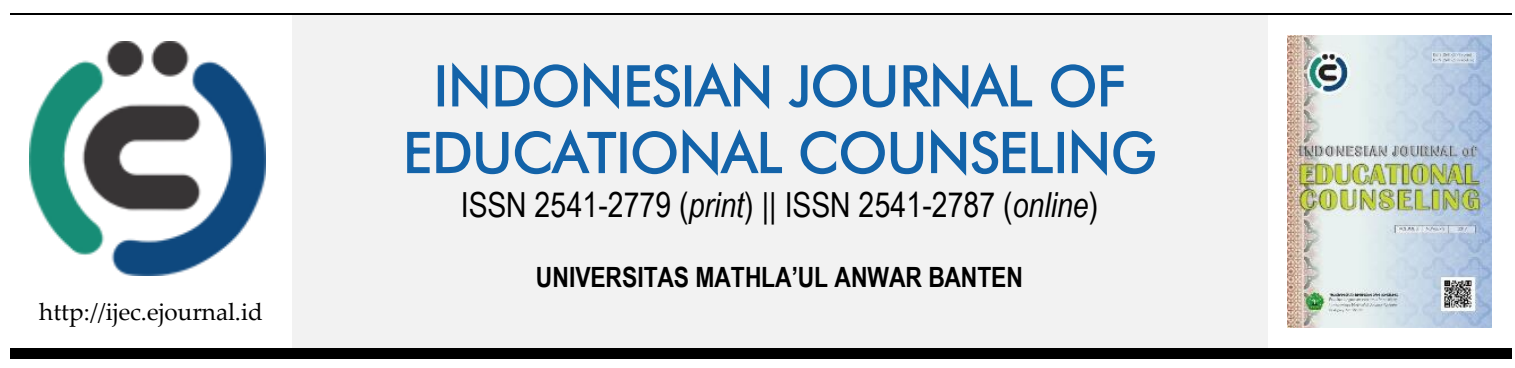

Research Based Article

\title{
Layanan Informasi Karier Berbasis Field Trip untuk Meningkatkan Pemahaman Karier Siswa
}

\author{
Hijrah Eko Putro ${ }^{1}$, Muhammad Japar ${ }^{2}$ \\ 1,2 Universitas Muhammadiyah Magelang
}

\begin{tabular}{|c|c|}
\hline Article History & ABSTRACT \\
\hline \multirow[t]{2}{*}{$\begin{array}{l}\text { Received: } 25.03 .2019 \\
\text { Received in revised form: } \\
01.04 .2019 \\
\text { Accepted: } 10.04 .2019 \\
\text { Available online: } 05.08 .2019\end{array}$} & $\begin{array}{l}\text { CAREER INFORMATION SERVICES BASED ON FIELD TRIP TO IMPROVE } \\
\text { STUDENTS UNDERSTANDING. The aims of this study is to: (1) find out the } \\
\text { implementation of career information services in Magelang Regency; (2) } \\
\text { produce career information service models with field trip techniques to } \\
\text { improve career understanding of vocational students; (3) determine the level of } \\
\text { career understanding of students in Muhammadiyah } 1 \text { Mertoyudan Vocational } \\
\text { School; and (4) knowing the effectiveness of career information services with } \\
\text { field trip techniques to improve career understanding of students at } \\
\text { Mertoyudan } 1 \text { Muhammadiyah Vocational School. The population in this study } \\
\text { were students of class XII of Muhammadiyah } 1 \text { Mertoyudan Vocational School } \\
\text { with } 29 \text { students who were used as samples. The study design used pre- } \\
\text { experimental: one group pretest-posttest design with saturated sampling. The } \\
\text { data analysis technique used is Paired sample t-Test with consideration in this } \\
\text { study using one independent variable (Independent Variable). The result of the } \\
\text { effectiveness test of this study is that there is an increase in students' career } \\
\text { understanding through career information services with field trip techniques. } \\
\text { The level of career understanding of students has increased after participating } \\
\text { in career information services with field trip techniques. This is seen from the } \\
\text { increase in the results of the student's career understanding scale before and } \\
\text { after being given career information services with a field trip technique of } 28 \% \\
\text { and strengthened through the effectiveness test using a t-test that shows the -t } \\
\text { count <-t-table, which is }-9,583<-2,045 \text { or data Sig }(0,000)<0.05 \text {. }\end{array}$ \\
\hline & $\begin{array}{l}\text { KEYWORDS: Career Information Services, Career Understanding, Field trip } \\
\text { Techniques. }\end{array}$ \\
\hline
\end{tabular}

DOI: 10.30653/001.201933.105

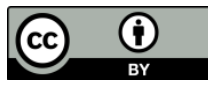

This is an open access article distributed under the terms of the Creative Commons Attribution 4.0 International License, which permits unrestricted use, distribution, and reproduction in any medium, provided the original work is properly cited. (c) 2019 Hijrah Eko Putro, Muhammad Japar.

\section{PENDAHULUAN}

Salah satu tugas perkembangan utama remaja adalah memilih suatu pilihan karier untuk masa depannya (Mendatu dalam Yeni, 2013, p. 201). Pemilihan karier menjadi sangat krusial bagi siswa SMK, karena untuk menentukan pemilihan pekerjaan atau 
pemilihan jurusan studi lanjut. Jika untuk memilih sebuah pekerjaan maka siswa harus memahami karier untuk mempersiapkan diri memasuki dunia kerja.

Donald E Super (Fitria, 2011) menyebut bahawa pemahaman karier adalah membantu pribadi untuk mengembangkan kesatuan dan gambaran diri serta peranannya dalam dunia kerja. Sedangkan menurut Tolbert (Fitria, 2011) pemahaman karier adalah suatu program yang disusun untuk menolong perkembangan anak agar mengerti akan dirinya, mempelajari dunia kerja untuk mendapatkan pengalaman yang akan membantu dalam membuat keputusan dan mendapatkan pekerjaan (Zuchri, 2017).

Pemahaman karier merupakan suatu kondisi dimana individu mampu mengembangkan keadaan dirinya dalam membuat keputusan karier (Darmasaputro \& Gunawan, 2018). Siswa SMK yang sudah memiliki pemahaman karier yang baik ditandai dengan sudah memahami potensi diri, memiliki informasi karier, mampu memilih pekerjaan sesuai dengan potensi diri atau keadaan dirinya.

Hasil wawancara dengan konselor (guru BK) dan beberapa siswa dalam penelitian pendahuluan menginformasikan bahwa siswa kelas XI SMK PGRI Wonoasri banyak yang belum memiliki pemahaman karier atau dapat dikatakan pemahaman karier siswa masih rendah, terlihat siswa masih belum banyak mengetahui cara memperoleh pekerjaan dan belum memahami pekerjaan yang sesuai dengan potensi. Selain itu, penelitian pendahuluan juga dilakukan di SMK Negeri 2 Jiwan. Menurut hasil wawancara dengan konselor sekolah diperoleh keterangan bahwa masih ada siswa yang pemahaman kariernya rendah, terbukti siswa belum memiliki informasi tentang dunia kerja misalkan syarat, tugas, prospek kedepan dan peluang dari pekerjaan.

Fakta di atas menunjukkan bahwa siswa belum memiliki tingkat penguasannya terhadap berbagai informasi karier atau belum memiliki informasi tentang dunia kerja misalkan syarat, tugas, prospek ke depan dan peluang dari pekerjaan, belum memiliki pengetahuan tentang cara memperoleh pekerjaan dan masih bingung menentukan kemana akan bekerja nantinya sesuai dengan potensi yang dimilikinya. Siswa yang memiliki pemahaman karier yang baik dan ditunjang dengan tingkat pemahaman dirinya juga baik akan menunjang terhadap kegiatan perencanaan karier, penyusunan alternatif pilihan karier, evaluasi alternatif pilihan karier dan pengambilan keputusan karier. Hal inilah yang menjadi alasan peneliti melakukan penelitian, agar siswa mampu meningkatkan pemahaman karier siswa.

Berbagai cara dilakukan dalam upaya pencegahan maupun penanganan masalah siswa yang ada di sekolah, seperti bimbingan belajar, bimbingan pribadi sosial, bimbingan karier, juga bimbingan kelompok, tetapi permasalahan tersebut masih nampak, dan membutuhkan penanganan yang lebih baik. Salah satu cara mengatasi masalah tersebut dengan memanfaatkan media bimbingan dan konseling untuk menyampaikan tentang informasi karier.

Untuk mengatasi masalah pemahaman karier ini layanan yang tepat adalah layanan bimbingan karier. Dalam pelaksanaan layanan bimbingan karier penggunaan media bimbingan sebaiknya tidak dilupakan, mengingat bahwa bimbingan dan konseling merupakan suatu sistem, dimana media menjadi salah satu komponen sistem. Hal ini senada dengan yang diungkapkan oleh Nursalim (2010, p. 5) bahwa bimbingan dan konseling dikatakan sebagai sistem karena di dalamnya mengandung komponen yang 
saling berkaitan untuk mencapai suatu tujuan yang telah ditetapkan. Komponen tersebut meliputi: masalah, tujuan, teknik, media dan evaluasi.

Terdapat berbagai macam media bimbingaan dan konseling yang dapat digunakan sebagai usaha pencegahan berkaitan dengan masalah kematangan karier siswa, diantaranya media cetak yang berupa modul. Nursalim, (2010, p. 14) menyatakan bahwa dalam bimbingan dan konseling modul ini sering digunakan sebagai modul bimbingan karier, modul bimbingan belajar dan lain sebagainya.

Hasil penelitian terdahulu yang dilakukan Dinar Mahdalena Leksana (2012) menunjukkan ada peningkatan kematangan karier siswa setelah dilaksanakan layanan bimbingan karier dengan menggunakan media interaktif sebanyak 10,2\%. Adapun penelitian yang dilakukan Yeny Muslihatul Khoiriyah (2013) menunjukkan adanya peningkatan pemahaman karier siswa sebanyak $10,31 \%$ setelah diberikan layanan informasi karier.

Penggunaan media bimbingan dan konseling juga tidak terlepas dari teknologi dan informasi yang ada di lingkungan sekitar kita. Informasi jabatan dapat diperoleh melalui membaca berita dari koran, menonton berita, dan membaca buku tentang informasi jabatan. Informasi jabatan juga telah disediakan oleh pemerintah melalui Departemen Tenaga Kerja dan Badan Statistik Negara yang menerbitkan Kualifikasi Baku Jenis Pekerjaan Indonesia (KBJI) dan Kualifikasi Jabatan Indonesia (KJI).

Modul perencanaan karier adalah salah satu bentuk usaha untuk memberikan informasi pada siswa agar siswa memahami tentang informasi jabatan dan memiliki pengetahuan tentang keputusan karier, sehingga dapat menentukan pekerjaan yang sesuai dengan potensi yang dimiliki lulusan Sekolah Menengah Kejuruan (SMK).

Setelah siswa memahami informasi karier yang sesuai dengan dirinya diharapkan siswa mampu memahami potensi dirinya, memahami tentang suatu pekerjaan dan mampu mengambil keputusan dalam menentukan pekerjaan. Dengan adanya gejala seperti ini dapat dikatakan siswa memiliki pemahaman karier yang baik.

\section{Informasi Karier}

Sumber dari informasi adalah data. Data diartikan sebagai segala fakta, angka, statistik yang dikumpulkan, disimpan, diproses yang dari data-data tersebut dapat diambil kesimpulan. Adapun informasi adalah data yang diolah, sehingga memiliki manfaat (Sutabri, 2012). Informasi dapat juga diartikan sebagai data yang diolah menjadi bentuk yang lebih berguna dan berarti bagi penerimanya (Hutahaean, 2015). Adapun menurut Griffin dan Ebert (2006), informasi adalah interpretasi data yang berarti dan berguna untuk membuat keputusan. Menurut Anton M. Moeliono (1988), informasi adalah penerangan, keterangan, pemberitahuan, kabar atau berita. Informasi juga merupakan keterangan atau bahan nyata yang dapat digunakan sebagai dasar kajian analisis dan kesimpulan.

Berdasarkan pendapat para ahli di atas dapat disimpulkan bahwa informasi adalah suatu data yang telah didapatkan dari media yang yang diolah sebagai dasar untuk membuat sebuah keputusan. Ketersediaan informasi merupakan hal penting bagi konselor untuk melengkapi ruang layanan bimbingan dan konseling dengan bahan informasi yang selengkap mungkin dan yang beraneka ragam. Bahan tersebut terutama informasi tentang pendidikan dan informasi tentang pekerjaan. 
Menurut Tyler (dalam Munandir, 1996, p. 191) bahan informasi karier sebaiknya memiliki ciri akurat dan bersifat kebaruan (update). Keakuratan berkenaan dengan andal atau dapat dipercaya. Informasi yang akurat tidak mengandung prasangka, bias dan sumber informasi berasal dari sumber yang berwenang. Informasi yang dimuat hendaknya baru, jika tidak baru akan menyesatkan, tidak ada gunanya dan memberikan informasi yang tidak mutakhir untuk keperluan perencanaan karier.

Menurut Persons (dalam Winkel \& Hastuti, 2006), ada tiga aspek yang harus dipenuhi dalam membuat suatu perencanaan karier, yaitu: 1) Pengetahuan dan pemahaman diri sendiri, yaitu pengetahuan dan pemahaman akan bakat, minat, kepribadian, potensi, prestasi akademik, ambisi, keterbatasa-keterbatasan dan sumbersumber yang dimiliki; 2) Pengetahuan dan pemahaman dunia kerja, yaitu pengetahuan akan syarat-syarat dan kondisi-kondisi yang dibutuhkan untuk akses dalam rugian, kompensasi, kesuatu pekerjaan, keuntungan dan kesempatan dan prospek kerja diberbagai bidang dalam dunia kerja; 3) Penalaran yang realistis akan hubungan pengetahuan dan pemahaman diri sendiri dengan pengetahuan dan pemahaman dunia kerja, yaitu kemampuan untuk membuat suatu penalaran realistis dalam suatu perencanaan atau memilih bidang kerja dan/ atau pendidikan kelanjutan yang mempertimbangkan pengetahuan dan pemahaman diri yang dimiliki dengan pengetahuan dan pemahaman dunia kerja yang tersedia.

\section{Teknik Field trip}

Teknik field trip ialah cara mengajar yang dilaksanakan dengan mengajak siswa ke suatu tempat atau obyek tertentu di luar sekolah untuk mempelajari atau menyelidiki sesuatu seperti meninjau pabrik sepatu, bengkel mobil, toko serba ada, peternakan, perkebunan, lapangan bermain dan sebagainya (Roestiyah, 2001, p. 85). Berbeda halnya dengan tamasya di mana seseorang pergi untuk mencari hiburan semata, field trip sebagai teknik belajar mengajar lebih terikat oleh tujuan dan tugas belajar. Sedangkan menurut Sagala (2006, p. 214) teknik field trip ialah pesiar (ekskursi) yang dilakukan oleh para peserta didik untuk melengkapi pengalaman belajar tertentu dan merupakan bagian integral dari kurikulum sekolah. Teknik field trip adalah salah satu teknik yang bertujuan untuk menambah wawasan siswa (Romlah, 2006, p. 28).

Berdasarkan beberapa pendapat di atas dapat disimpulkan bahwa teknik field trip merupakan teknik penyampaian materi pelajaran dengan cara membawa langsung siswa ke obyek tertentu di luar kelas atau di luar lingkungan sekolah agar siswa dapat mengamati atau mengalami secara langsung yang bertujuan untuk belajar. Teknik field trip disanggap peneliti sebagai salah satu teknik yang efektif digunakan sebagai teknik pembelajaran khususnya dalam meningkatkan perencanaan karier siswa.

Layanan informasi karier terdapat beberapa metode yang salah satunya adalah field trip (Anisah, 2015). Field trip yaitu metode yang menggunakan karyawisata, agar para siswa bebas mengekspresikan isi hati secara leluasa. Teknik field trip adalah salah satu teknik yang bertujuan untuk menambah wawasan siswa (Romlah, 2006, p. 28). Kelebihan dari metode ini adalah (1) field trip memiliki prinsip pengajaran modern yang memanfaatkan lingkungan nyata dalam pengajaran, (2) membuat apa yang dipelajari di sekolah lebih relavan dengan kenyataan dan kebutuhan masyarakat, (3) Pengajaran serupa ini dapat lebih merangsang kreativitas siswa, (4) Informasi sebagai bahan pelajaran lebih luas dan aktual (Djamarah, 2006, p. 94). 
Teknik karyawisata atau field trip mempunyai beberapa kelebihan antara lain (Djamarah, 2006, p. 94): 1) Prinsip pengajaran modern yang memanfaatkan lingkungan nyata dalam pengajaran; 2) Membuat apa yang dipelajari di sekolah lebih relavan dengan kenyataan dan kebutuhan masyarakat; 3) Merangsang kreativitas siswa; 4) Informasi sebagai bahan pelajaran lebih luas dan aktual.

Adapun menurut Roestiyah (2001, p. 87) menyatakan kelebihan teknik karyawisata atau field trip yaitu: 1) Siswa memperoleh pengalaman belajar yang tidak didapatkan di sekolah, sehingga kesempatan tersebut dapat mengembangkan bakat khusus atau keterampilan siswa; 2) Siswa dapat melihat berbagai kegiatan di lingkungan luar sehingga dapat memperdalam dan memperluas pengalaman siswa;3) Dengan obyek yang ditinjau langsung, siswa dapat memperoleh bermacam-macam pengetahuan dan pengalaman yang terintegrasi dan tidak terpisah-pisah dan terpadu.

\section{Pemahaman Karier}

Menurut Sudijono (1998), pemahaman (comprehension) merupakan kemampuan seseorang untuk mengerti atau memahami sesuatu setelah sesuatu itu diketahui dan diingat. Gordon (dalam Mulyasa, 2010, p. 39) menyebut bahwa pemahaman (understanding) merupakan kesadaran dalam bidang kognitif dan afektif yang dimiliki individu. Sedangkan menurut Winkel pemahaman yaitu kemampuan seseorang untuk mengerti atau memahami sesuatu setelah sesuatu itu diketahui atau diingat; mencakup kemampuan untuk menangkap makna dari arti dari bahan yang dipelajari, yang dinyatakan dengan menguraikan isi pokok dari suatu bacaan, atau mengubah data yang disajikan dalam bentuk tertentu ke bentuk yang lain.

Lebih lanjut, Bloom (dalam Santrock, 2010, p. 468) menjelaskan bahwa memasukkan pemahaman ke dalam kawasan kognitif, yaitu kawasan yang berkaitan dengan aspekaspek intelektual atau berpikir/nalar. Dengan demikian, pemahaman, diartikan sebagai kemampuan seseorang dalam memahami informasi dan dapat menerangkannya dengan kalimat mereka sendiri. Yang termasuk dalam kemampuan ini antara lain, menjelaskan, menginterpretasikan, memberikan contoh, memperkirakan, memprediksi, menyimpulkan, dan merencanakan.

Pemahaman diri atau disebut knowing yourself oleh Levinson, Ohler, Caswell dan Kiewra (1998) merupakan aspek penting dalam pengambilan keputusan, dan kemampuan siswa dalam pengambilan keputusan karier merupakan wujud nyata dari kematangan perkembangan karier siswa. Sedangkan kematangan karier menurut Super (dalam Hartono, 2010, p. 63) memilki enam dimensi, yaitu; (1) dimensi membuat pilihan karier, (2) dimensi kompetensi khusus tentang mencari informasi karier dan keterampilan-keterampilan membuat perencanaan karier, (3) dimensi konsistensi pilihanpilihan, (4) dimensi pengenbangan konsep diri, (5) dimensi kebebasan membuaat keputusan karier, dan (6) dimensi konsistensi membuat pilihan yang realistis berdasarkan tujuan pribadi.

\section{METODE}

Metode dalam penelitian ini adalah quasi eksperimen, dengan rancangan pretestposttest. Para siswa diukur karakteristik pemahaman diri dengan menggunakan skala pemahaman diri. Seluruh subjek penelitian dimasukkan ke dalam satu kelompok yaitu 
kelompok eksperimen tanpa kelompok kontrol (One Group Pretest-Posttest Design). Kelompok eksperimen diberi perlakuan berupa Layanan Informasi Perencanaan karier berbasis field trip. Rancangan pengukuran tersebut dapat dilihat pada Tabel 1.

Tabel 1. Rancangan Penelitian

\begin{tabular}{llll}
\hline Kelompok & Pretest & Perlakuan & Posttest \\
\hline Eksperimen & $\mathrm{O} 1$ & $\mathrm{X}$ & $\mathrm{O} 2$ \\
\hline
\end{tabular}

Keterangan :

O1 : Pretest

O2 : Posttest

X : Perlakuan (Layanan Informasi karier berbasis field trip)

Penelitian ini, jenis sampel yang digunakan adalah sampling jenuh. Subyek penelitian ini ditetapkan siswa-siswi kelas XII SMK Muhammadiyah 1 Mertoyudan.

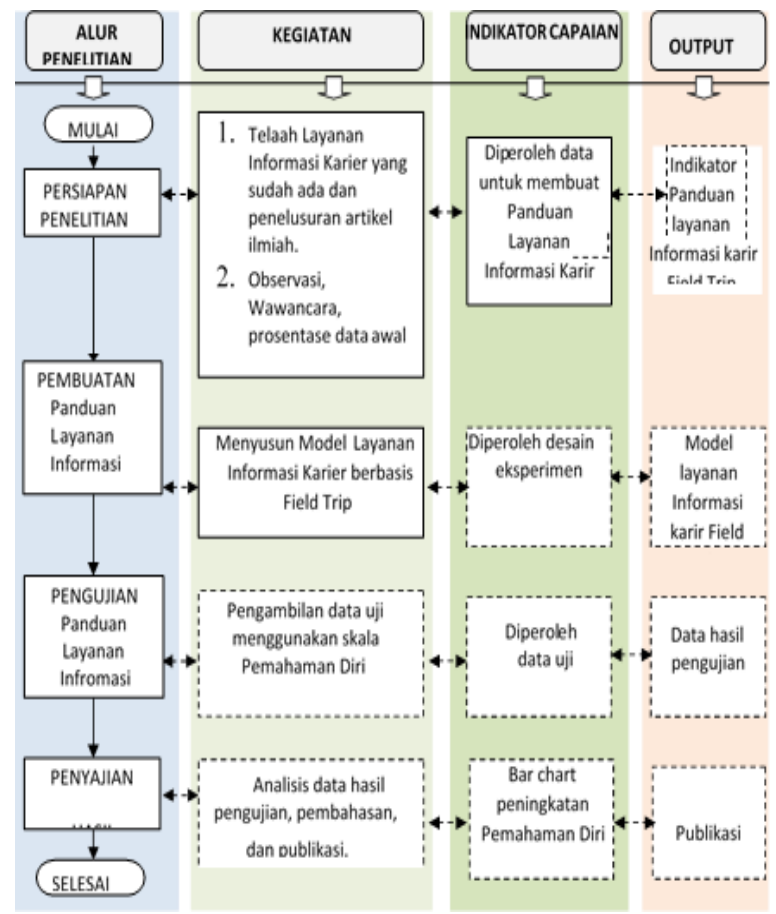

Gambar 1. Bagan Alur Penelitian

Teknik dan instrumen pengumpulan data menggunakan teknik wawancara, obeservasi, dan skala pemahaman karier. Teknik pengambilan sampel menggunakan non random sampling. Analisis data menggunakan analisis data kualitatif deskriptif untuk pelaksanaan layanan informasi perencanaan karier, sedangkan untuk analisis data skala menggunakan analisis data kuantitatif dengan menggunakan uji-t.

Setelah semua data terkumpul secara lengkap dan sistematis, maka selanjutnya adalah menganalisis data agar menjadi satu fakta sehingga dapat ditarik kesimpulan atas dasar fakta tersebut dengan menggunakan progam statistik yakni cara-cara ilmiah untuk mengumpulkan, menyajikan, menyusun dan menganalisis data yang berwujud angka. Pada penelitian ini sesuai dengan rumusan permasalahan dan tujuan penelitiannya, maka 
pengolahan dan analisis datanya menggunakan analisis Paired Sample T-test. Analisis dengan menggunakan Paired Sample T-test dengan pertimbangan dengan penelitian ini menggunakan satu variabel bebas (independent variable), sedangkan progam statistik yang digunakan dalam analisis data adalah SPSS For Windows Versions 22.0.

\section{HASIL DAN PEMBAHASAN}

Analisis data yang dilakukan dalam penelitian ini bertujuan untuk membuktikan atau menguji hipotesis yang di kemukakan sebelumnya. Adapun teknis analisis data yang digunakan adalah menggunakan SPSS versi 23.0 sehingga mempermudah penghitungan data yang didapatkan. Analisis data penelitian ini adalah menggunakan tahapan pengolahan analisis sebagai berikut :

Setelah diperoleh data penelitian baik data pre-test dan post-test, maka langkah selanjutnya adalah melakukan analisis data. Analisis data yang ingin digunakan untuk menguji hipotesis yang di ajukan sebelumnya. Hasil pengujian hipotesis tersebut, selanjutnya akan digunakan sebagai pembahasan permasalahan yang ada.

Paired Sample T-test adalah uji yang dilakukan terhadap dua sampel yang berpasangan (paired). Sampel yang berpasangan diartikan sebagai sebuah sampel dengan subyek yang sama, namun mengalami dua perlakuan atau pengukuran yang berbeda.

Uji keefektifan layanan informasi karier berbasis field trip dengan statistic parametric melalui uji paired samples t-test. Perhitungan menggunakan SPSS 23.0 hasil perhitungan dapat ditunjukan pada Tabel 2.

Tabel 2. Hasil Perhitungan Paired Sample T-test

\begin{tabular}{ccc}
\hline $\mathrm{t}$ & $\mathrm{df}$ & Sig.(2-tailed) \\
\hline$-9,583$ & 28 & .000 \\
\hline
\end{tabular}

Berdasarkan hasil perhitungan pada Tabel 2, dapat diketahui bahwa thitung $(-9,583)$ $<\mathrm{t}$ tabel $(-2,045)$, jadi Ho (Hipotesis Nol ditolak) sehingga dapat disimpulkan bahwa ada perbedaan skala pemahaman karier siswa antara sebelum dan sesudah dilaksanakan layanan informasi karier berbasis field trip untuk meningkatkan pemahaman karier siswa.

Pengambilan keputusan kedua yaitu berdasarkan signifikansi, dapat diketahui bahwa signifikansi dari tabel sebesar 0,000 lebih kecil dari 0,05 maka Ho ditolak dan Ha diterima. Kesimpulannya bahwa ada perbedaan skala pemahaman karier siswa sebelum dan sesudah dilaksanakan layanan informasi karier berbasis field trip, sehingga layanan informasi karier berbasis field trip efektif untuk meningkatkan pemahaman karier siswa SMK Muhammadiyah 1 Mertoyudan.

Untuk menyimpulkan efektif tidaknya layanan informasi karier yang telah dilakukan terhadap responden, peneliti mendasarkan pada argumen yang dibangun, yakni: Layanan dapat dikatakan efektif jika dominan responden mengalami kenaikan skor pemahaman karier setelah dilakukan perlakuan.

Dalam hasil analisis terbukti terdapat peningkatan rata-rata pemahaman karier siswa dalam angket evaluasi awal (pre-test) dan evaluasi akhir (post-test), sehingga ada pengaruh layanan layanan informasi karier berbasis field trip. Bukti peningkatan pemahaman karier siswa dapat di lihat dalam tabel skor atau perbandingan antara hasil evaluasi awal (pre-test) dan evaluasi akhir (post-test). 


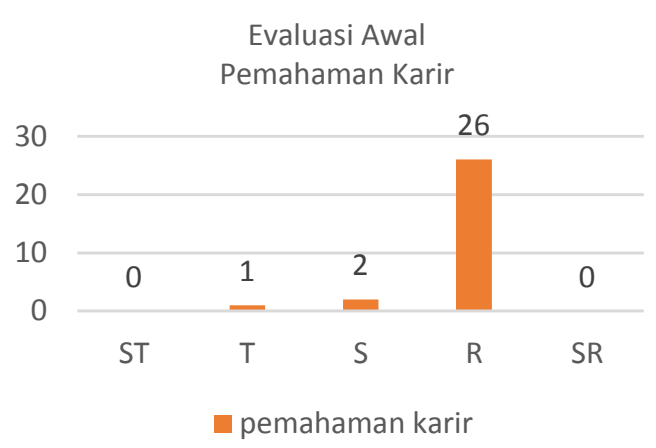

Gambar 2. Histogram Skala Pemahaman Karier Sebelum Perlakuan

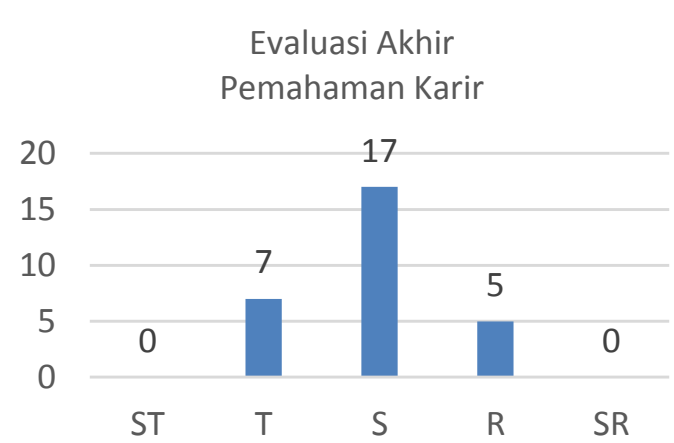

Gambar 3. Histogram Skala Pemahaman Karier Sebelum Perlakuan

Perbandingan

EV 1 \& EV 2

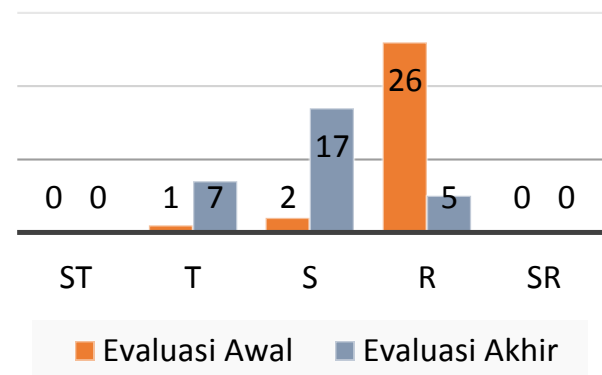

Gambar 4. Histogram Perbandingan Skala Sebelum \& Setelah Perlakuan

Hasil penelitian selanjutnya berkaitan tentang gambaran pemahaman karier siswa. Tingkat pemahaman karier siswa yang menjadi angggota kelompok sebelum dan sesudah memperoleh layanan informasi karier berbasis field trip mengalami peningkatan sebesar $28 \%$.

Hasil uji efektivitas dari penelitian ini adalah: pemahaman karier siswa sebelum diberikan layanan informasi karier berbasis field trip adalah 29 siswa terdiri dari 1 siswa dengan katagori tinggi, 2 siswa dengan katagori sedang, 26 siswa dengan katagori rendah, pemahaman karier siswa setelah diberikan layanan informasi karier berbasis field trip 
adalah 29 siswa terdiri dari 7 siswa dengan katagori tinggi, 17 siswa dengan katagori sedang dan 5 dengan kategori rendah.

\section{SIMPULAN}

Pelaksanaan layanan informasi karier masih belum maksimal. Layanan informasi karier yang laksanakan antara lain: (a) layanan informasi karier dilakukan melalui pamplet/ leaflet, (c) tahap-tahap dalam layanan informasi karier belum dilaksanakan dengan maksimal, (d) topik yang dibahas dalam layanan informasi karier berfokus pada kesiapan pemagangan, (e) belum mengaplikasikan teknik yang terdapat dalam layanan informasi karier, Disamping itu, layanan informasi karier yang diberikan berfokus pada mempersiapkan siswa dalam melaksanakan tugas magang dari sekolah.

Layanan informasi karier merupakan salah satu bentuk layanan yang penting di selenggarakan oleh sekolah. Kegiatan belajar yang dilaksanakan di sekolah, tentu tidak bisa lepas dari adanya kegiatan belajar mengajar dan juga faktor-faktor yang dapat mempengaruhinya terhadap proses belajar mengajar antara lain anak didik, pendidik, pembimbing, kurikulum, metode juga sarana dan prasarana. Dalam penelitian ini penulis mengangkat metode yang digunakan adalah " layanan informasi karier berbasis field trip efektif untuk meningkatkan pemahaman karier kelas XII ternyata terbukti dengan adanya perubahan atau peningkatan skor siswa setelah di laksanakan treatment atau perlakuan. Simpulan ini didasarkan pada perbedaan skor evaluasi awal dan evaluasi akhir, di mana ada peningkatan tingkat pemahaman karier siswa sebelum dan sesudah diberi layanan informasi karier berbasis field trip sebesar $28 \%$. Hasil ini diperkuat melalui uji efektivitas menggunakan $\mathrm{t}$-test yang menunjukan $-\mathrm{t}$ hitung $<-\mathrm{t}$ tabel, yaitu $(-9,583)<\mathrm{t}$ tabel $(-2,045)$.

\section{REFERENSI}

Anisah, L. (2015). Model layanan informasi karir dengan teknik field trip untuk meningkatkan perencanaan karir siswa SMK di Kabupaten Demak. Jurnal Konseling Gusjigang, 1(1), 1-10.

Arikunto, S. (2006). Prosedur penelitian suatu pendekatan dan praktik. Jakarta: Rineka Cipta.

Darmasaputro, A., \& Gunawan, W. (2018). Hubungan efikasi diri pengambilan keputusan karier dan pengambilan keputusan karier pada siswa SMA. Jurnal Psikologi, 14(1), 111.

Djamarah, S. B. (2006). Strategi belajar mengajar (Edisi revisi). Jakarta: Rineka Cipta.

Gibson, R. L., \& Mitchell, M. H. (2010). Bimbingan dan konseling. Yogyakarta: Pustaka Pelajar.

Griffin, R. W., \& Ebert, R. J. (2006). Bussines. New Jersey: Prentice Hall.

Hadi, S. (2000). Metodologi research. Yogyakarta: UGM. 
Hartono. (2010). Bimbingan karier berbantuan komputer untuk siswa SMA. Surabaya: Unipa Press.

Hutahaean, J. (2015). Konsep sistem informasi. Yogyakarta: Deepublish.

Kemendiknas. (2010). Permendiknas no. 2 tentang restra kemendiknas tahun 2010-2014. Jakarta: Kementrian Pendidikan Nasional RI.

Levinson, E. M., Ohlers, D. L., Caswell, S., \& Kiewra, K. (1998). Six approaches to the assessment of career maturity. Journal of Counseling \& Development, 76(4), 475-482.

Moeliono, A. M. (1988). Kamus besar bahasa Indonesia. Jakarta: Balai Pustaka.

Mulyasa, E. (2010). Penelitian tindakan kelas. Bandung: Remaja Rosdakarya.

Munandir. (1996). Program bimbingan karir di sekolah. Jakarta: Departemen Pendidikan dan Kebudayaan.

Nurihsan, A. J. (2005). Strategi layanan bimbingan dan konseling. Bandung: Refika Aditama.

Pasquier, M., \& Narguizian, P. J. (2006). Using nature as a resource: Effectively planning an outdoor field trip. Science Activities, 43(2), 29-33.

Roestiyah, N. K. (2001). Strategi belajar mengajar. Jakarta: Rineka Cipta.

Romlah, T. (2006). Teori dan praktek bimbingan kelompok. Malang: Universitas Negeri Malang.

Sagala, S. 2006. Konsep dan makna pembelajaran. Bandung: Alfabeta

Santrock, J. (2010). Adolescence, 13th international ed. New York: McGraw-Hill.

Sudijono, A. (1998). Pengantar evaluasi pendidikan. Jakarta: RajaGrafindo.

Sugiyono. (2011). Metode penelitian pendidikan: Pendekatan kuantitatif, kualitatif dan RED. Bandung: Alfabeta.

Sutabri, T. (2012). Konsep sistem informasi. Yogyakarta: Penerbit Andi.

Walgito, B. (2010). Bimbingan dan konseling (Studi dan karier). Yogyakarta: Penerbit Andi.

Winkel, W. S., \& Hastuti, M. M. S. (2006). Bimbingan dan konseling di institusi pendidikan. Jakarta: Grasindo.

Zuchri, S. (2017). Manipulatif berbantuan geogebra untuk membantu pemahaman siswa dalam menyelesaikan word problem kelas 7 SMP. Euclid, 4(2), 780-789. 